\title{
Self-compassion as a predictor of social physique anxiety in athletes
}

\author{
Hatice Epli Koç ${ }^{1}$ \\ Egemen Ermiş ${ }^{2}$
}

\begin{abstract}
The purpose of this study is to examine the explanatory effect of self-compassion on social physique anxiety in athletes. The study was conducted with the participation of a total of 462 athletes, 145 female and 317 male, who were studying at Yaşar Doğu Faculty of Sport Sciences. Self-compassion Scale and Social Physique Anxiety Scale (SPAS) were used in the study. Independent sample t-test analysis showed that average scores of athletes for physical appearance comfort $(\mathrm{PAC}) t(250)=.158, p>0,5)$ and expectations of negative evaluation (ENE), $t(262)=.649$, $p>0,5$ did not show a significant difference in terms of gender. According to the results of Pearson Product-Moment Correlation analysis, negative significant association was found between PAC subscale of social physique anxiety and self-kindness, common humanity and mindfulness dimensions of self-compassion while a positive significant association was found between selfjudgment, isolation and over identification. Negative significant association was found between ENE subscale of social physique anxiety and self-kindness and mindfulness dimensions of selfcompassion while a positive significant association was found between self-judgment, common humanity, isolation and over identification. Multiple regression analysis results presented the high level explanatory effect of self-compassion levels and the PAC of social physique anxiety , $R=0.60$, $R^{2}=0.36, p<.01$. Similarly, explanatory effect of ENE area of social physique anxiety, $R=0.38$, $\mathrm{R}^{2}=0.15, p<.01$ was also presented.
\end{abstract}

Keywords: Social physical anxiety; self-compassion; athletes.

\section{Introduction}

Today, body is no more within an individual's own will, disposal and domination, it has become the area of action of dominant and widespread norms through media and mass culture (Özdemir, 2014). Under these circumstances, while an individual is interested in his/her physique on the one hand, s/he is also interested in the physique of others on the other hand. The thought that the opposite side also does the same thing causes an individual to experience anxiety (Aşc1, Tüzün \& Koca, 2006). This anxiety, which is defined as social physique anxiety, arises when an individual thinks that this/her social environment can make negative evaluations about his/her physical appearance and it presents as a subtype of social anxiety associated with image of the body (Hart, Leary, \& Rejeski, 1989). Social physique anxiety, which advocates that people have a tendency to control how they look in front of the others and which is based on self-presentation, has been reported to manifest when people think that they are insufficient about creating the image they want about their physique in front of the eyes of other people (Hagger \& Stevenson, 2010).

\footnotetext{
1 Res. Assist. Dr., Ondokuz Mayis University, Faculty of Education, Department of Educational Sciences, hatice.eplikoc@omu.edu.tr

2 Assist. Prof. Dr., Ondokuz Mayis University, Yaşar Doğu Faculty of Sports Sciences/Department of Coaching Education, egemen.ermis@,omu.edu.tr
} 
While social physique anxiety can affect all the individuals who give priority to physique, it has largely been associated with exercise groups (Eklund \& Crawford, 1994; Crawford\& Eklund, 1994; Hurst, Hale, Smith \& Colins, 2000), exercise motivation (Sicilia, Alvarez, Cutre \& Ferriz, 2014) and the trait anxiety states of athletes (Martin \& Mack, 1996) in sports competitions and has been addressed thus. Sport is a condition which also includes competition and it causes athletes to experience pressure. Since athletes are evaluated not only in terms of performance, but also appearance, a great number of athletes struggle with the problems about their bodies. It is frequently difficult to keep balance of appearance and performance targets. This performanceappearance balance difficulty is more remarkable especially for young female athletes (Mosewich, 2013). Studies have revealed that athletes cannot protect themselves from the anxiety of reaching the ideal physique; in terms of gender, studies have shown that male athletes can feel anxious in front of the spectators during the game; however, a female athlete feels more pressure about her appearance and how she is evaluated on account of her physique and they are more anxious (Krane, Stiles-Shipley, Waldron, \& Michalenok, 2001; Greenleaf, 2002; Mosewich, Vangol, Kowalski \& McHugh, 2009).

Self-compassion, which is stated to be a very suitable tool to decrease the harmful effects of all these negative self- assessments of individuals (Neff, 2009), is defined as a person's being open to these feelings which cause him/her to experience problems, being attentive and loving to himself/herself, being understanding and unprejudiced to his/her inabilities and failures and accepting the negative experiences as a part of human life (Neff, 2003a)

Neff (2003b) proposed that self-compassion consists of three components as self-kindness, common humanity and mindfulness. Self-kindness is an individual's trying to understand himself/herself without prejudices, and being kind and loving to his/her self rather than having harsh judgments and criticizing. Common humanity means being aware of sharing, being aware that the happy or sad experiences of life are not specific to a person and that all other human beings experience similar things. The third component of self-compassion, mindfulness, is an awareness that enables an individual to accept the problematic or sad feelings of life without allowing him/her to drift away by these feelings.

When studies about self-compassion are considered, it can be seen that they focus on variables related to psychological well-being. Neffs (2003a) study showed that rumination tendencies of high levels of self-compassion were negatively associated with depressive symptoms and anxiety and that individuals who were more self-compassionate showed less negative mental health symptoms. Other researches have shown high levels of self-compassion to be associated with general life satisfaction, social commitment, emotional intelligence, optimism, happiness and personal initiative and low levels of self-compassion to be negatively associated with eating disorders, performance purposes, perfectionism, suppressed thoughts and self-criticism (Neff, Hseih, \& Dejitthirat, 2005; Adams \& Leary, 2007; Neff \&Vonk, 2009; Campos et al. 2015; Hollis-Walker \& Colosimo, 2011; Heffernan et al. 2010; Pyszczynski et al., 2004) which are similar to present findings.

Individuals who face with their own limitations and inabilities mostly over identify with these limitations and inabilities with a harsh and narrow point of view and develop negative thoughts and feelings for themselves, they ignore that failure and not being perfect are frequently shared human experiences and these cause individuals to experience isolation and loneliness by driving them to isolation (Neff \& Vonk, 2009). Within this context, self-compassion can be a strong source for athletes to cope with negative situations in sports such as failure, defeat, difficulty, problems and negative assessment, which athletes are frequently faced with (Neff, 2003b). In their study they focused on the potential benefits of self-compassion for physical activity motivation and self- 
Epli Koç, H., \& Ermiş, E. (2016). Self-compassion as a predictor of social physique anxiety in athletes. Journal of Human Sciences, 13(3), 5214-5222. doi:10.14687/ihs.v13i3.4120

assessment thoughts and behaviors among women, Magnus, Kowalski, \& McHugh (2010) found a negative association between self-compassion and social physique anxiety.

Since self-compassion is effective not only in decreasing negative self-assessment thoughts and behaviors, but also in decreasing feelings of guilt and shame caused by these assessments (Neff, 2003a), the purpose of this study is to examine the role of self-compassion in athletes' experiencing social physique anxiety since athletes have a potential to head for the ideal in terms of their appearances because their bodies are on the forefront.

With this purpose, answers will be sought to following questions: (1) Do athletes' social physique anxieties differ in terms of gender? (2) Is there a significant association between athletes' levels of social physique anxiety and their levels of self-compassion? (3) Are the self-compassion areas of athletes significant predictors of social physique anxiety?

\section{Method}

\section{Participants}

The study group consisted of randomly chosen 464 athletes studying at Ondokuz May1s University Yaşar Doğu Faculty of Sports Sciences during the academic year 2015-2016. The number of participants was 462 (145 female $M_{\text {age }}=21.3, S D=2.09$ and 317 male $M_{\text {age }}=22.23, S D=2.83$ ).

\section{Measures}

Self-Compassion scale (SCS). Self-compassion was measured by using Self-compassion Scale (Neff, 2003b). Turkish adaptation of this scale had been done by Akın, Akın, and Abac1 (2007). Self-compassion Scale is a 26-item self-report measurement and consists of six sub-scales; selfkindness, self-judgment, common humanity, isolation, mindfulness, and over-identification. Each item was rated on a 5 -point Likert scale (from $1=$ strongly disagree to $5=$ strongly agree). Language validity findings indicated that correlations between Turkish and English forms were .94, $.94, .87, .89, .92$, and .94 for six subscales, respectively. Results of confirmatory factor analysis indicated that the model was well fit. The goodness of fit index values of the model were RMSEA $=.056, \mathrm{NFI}=.95 \mathrm{CFI}=.97, \mathrm{IFI}=.97, \mathrm{RFI}=.94, \mathrm{GFI}=.91$, and $\mathrm{SRMR}=.059$. Cronbach alpha internal consistency coefficients were $.77, .72, .72, .80, .74$, and .74 and the test-retest reliability coefficients were $.69, .59, .66, .60 .69$, and .56 , for six subscales, respectively.

Social Physique Anxiety Scale. In order to determine physical education students' levels of social physique anxiety, the Social Physique Anxiety Scale(SPAS) developed by Hart, Leary \& Rejeski (1989) and adapted into Turkish by Mülazımoğlu-Ballı and Aşçı (2006) was used as a data collection instrument. The statements in the inventory are responded through a 5-point Likert scale. The inventory is composed of two sub-dimensions, namely, physical appearance comfort (PAC) and expectations of negative evaluation (ENE). The lowest possible score on the inventory is 12, while the highest is 60 . As the score on the inventory increases, so does the level of physical appearance anxiety of a person. The internal reliability coefficient of the inventory calculated on the sample of this study was found to be .79 .

Personal Information Form. The study used a personal information form which was prepared by the researchers to get information about the age and gender of the participants. Gender was asked in the form of closed multiple choice and the participants were asked to write their ages in openended form.

\section{Procedure and data analysis}

Data collection tools were conducted by the researchers in classes. After the process of collecting information was finished, the data obtained were prepared to conduct the suitable statistical 
Epli Koç, H., \& Ermiş, E. (2016). Self-compassion as a predictor of social physique anxiety in athletes. Journal of Human Sciences, 13(3), 5214-5222. doi:10.14687/ihs.v13i3.4120

procedure on computer. The information was analyzed by using SPSS. As for statistical analysis techniques, Independent Sample t-test analysis, Pearson Moments Correlation and Multiple Linear Regression analysis were used. Analysis results were reported in the results section.

\section{Results}

The results of the questions in the study are as follows: gender?

(1) Is there a significant difference between the athletes' social physique anxiety and their

In order to answer this question, first of all the data were examined in terms of being suitable for parametric techniques and it was found that they were normally distributed (Kolmogorov Smirnov $\mathrm{p}>$.05), thus Independent Sample t-test was used in analysis. Analysis results are given in Table 1.

Table 1.

Independent t-test results of Social Physique Anxiety dimension in terms of gender

\begin{tabular}{llllllc}
\hline Dimensions & Gender & $\mathrm{M}$ & $\mathrm{S}$ & $\mathrm{t}$ & $\mathrm{SD}$ & $\mathrm{p}$ \\
\hline PAC & Female & 12.21 & 3.86 & .158 & 250 & $\mathrm{p}>.05$ \\
& Male & 12.15 & 3.41 & & & \\
\hline ENE & Female & 17.38 & 5.51 & .649 & 262 & $\mathrm{p}>.05$ \\
& Male & 17.03 & 5.14 & & & \\
\hline$p>.05$ & & & & & &
\end{tabular}

As can be seen from Table 1, the athletes' physical appearance comfort score averages do not show a significant difference in terms of gender, $\mathrm{t}(250)=.158, \mathrm{p}>0.5$. The average scores of the dimension of the expectation of being evaluated negatively do not show a significant difference in terms of gender, $\mathrm{t}(262)=.649, \mathrm{p}>0.5$.

(2) Is there a significant association between the athletes' social physique anxiety levels and their self-compassion levels?

Pearson Moment Coefficient Correlation was used to answer the second question of the study. The results of Pearson Moment Coefficient Correlation which was conducted to answer the question "Is there a significant association between the athletes' social physique anxiety levels and their selfcompassion levels?” are given in Table 2.

Table 2

The association between the athletes Social Physique Anxiety levels and their Self-compassion levels

\begin{tabular}{lcccccc}
\hline & $\begin{array}{c}\text { Self } \\
\text { kindness }\end{array}$ & $\begin{array}{c}\text { Self- } \\
\text { judgment }\end{array}$ & $\begin{array}{c}\text { Common } \\
\text { humanity }\end{array}$ & Isolation & Mindfulness & $\begin{array}{c}\text { Over } \\
\text { identification }\end{array}$ \\
\hline PAC & -.34 & .31 & -.26 & .20 & -.52 & .27 \\
& $\mathrm{p}<.01$ & $\mathrm{p}<.01$ & $\mathrm{p}<.01$ & $\mathrm{p}<.01$ & $\mathrm{p}<.01$ & $\mathrm{p}<.01$ \\
\hline ENE & -.11 & .30 & .094 & .26 & -.095 & .27 \\
& $\mathrm{p}<.05$ & $\mathrm{p}<.01$ & $\mathrm{p}<.05$ & $\mathrm{p}<.01$ & $\mathrm{p}<.05$ & $\mathrm{p}<.01$ \\
\hline
\end{tabular}

$* \mathrm{p}<.01$

As can be seen from Table 2, a negative association was found between the physical appearance comfort dimension of social physique anxiety and self-kindness $(r=-.34, p<.01)$, common humanity $(r=-.26, p<.01)$, and mindfulness dimensions $(r=-.52, p<.01)$, of self-compassion, while a positive association was found between the physical appearance comfort and self-judgment $(r=.31, p<.01)$, isolation $(r=.20, p<.01)$, and over identification $(r=.27, p<.01)$. A negative association was found between the expectation of being evaluated negatively dimension of social physique anxiety and self-kindness $(r=-.11, p<.05)$, and mindfulness $(r=-.095, p<.05)$, 
Epli Koç, H., \& Ermiş, E. (2016). Self-compassion as a predictor of social physique anxiety in athletes. Journal of Human Sciences, 13(3), 5214-5222. doi:10.14687/ihs.v13i3.4120

dimensions of self-compassion, while a positive association was found between the expectation of being evaluated negatively and self-judgment $(r=.30, p<.01)$, common humanity $(\mathrm{r}=.094, p<.05)$, isolation $(\mathrm{r}=.26, p<.01)$, and over identification $(r=.27, p<.01)$. anxiety?

(3) Are the self-compassion areas of athletes significant predictors of social physique

Multiple linear regression analysis was used to answer this question. Two different analyses were made to find out whether the Social Physique Anxiety Scale was a predictor of the areas of physical appearance comfort and the expectation of being evaluated negatively and whether SelfCompassion Scale was a predictor of the areas of self-kindness, self-judgment, common humanity, isolation, mindfulness and over identification. The analyses results are given in Table 3.

Table 3

Multiple Linear Regression analysis about whether Self-compassion dimensions are predictors of Social Pbysique Anxiety dimensions

\begin{tabular}{|c|c|c|c|c|c|c|c|c|}
\hline & & & Standarc & & & & & \\
\hline & Variables & $B$ & Error & $\beta$ & $t$ & $P$ & $R$ & $R^{2}$ \\
\hline \multirow{7}{*}{ PAC } & Fixed & 16,50 & .872 & - & 18,916 & $.000 * *$ & - & - \\
\hline & Self-kindness & -.12 & .045 & -.122 & $-2,592$ & $.010^{*}$ & -.347 & -.121 \\
\hline & Self-judgment & .11 & 0.45 & .122 & 2,541 & $.011 *$ & .312 & .118 \\
\hline & $\begin{array}{l}\text { Common } \\
\text { humanity }\end{array}$ & -.06 & 0.54 & -.054 & $-1,136$ & .256 & -.259 & -.053 \\
\hline & Isolation & .10 & .047 & .097 & 2,118 & $.035^{*}$ & .198 & .099 \\
\hline & Mindfulness & -.41 & .043 & -.420 & $-9,641$ & $.000^{* *}$ & -.527 & -.412 \\
\hline & $\begin{array}{l}\text { Over } \\
\text { identification }\end{array}$ & .11 & .047 & .110 & 2,302 & $.022 *$ & .270 & .107 \\
\hline \multirow{7}{*}{ ENE } & Fixed & 12,014 & 1,493 & - & 8,047 & $.000^{* *}$ & - & - \\
\hline & Self-kindness & -.25 & .077 & -.177 & -3.222 & $.001^{* *}$ & -.114 & -.149 \\
\hline & Self-judgment & .21 & .076 & .151 & 2,714 & $.007 * *$ & .301 & .126 \\
\hline & $\begin{array}{l}\text { Common } \\
\text { humanity }\end{array}$ & .31 & .093 & .180 & 3,285 & $.001 * *$ & .094 & .152 \\
\hline & Isolation & .17 & .081 & .112 & 2,119 & $.035^{*}$ & .261 & .099 \\
\hline & Mindfulness & -.08 & .073 & .105 & $-1,051$ & .058 & -.095 & -.049 \\
\hline & $\begin{array}{l}\text { Over } \\
\text { identification }\end{array}$ & .15 & .081 & -.053 & 1,900 & .294 & .272 & .089 \\
\hline
\end{tabular}

As can be seen from Table 3, the results of the Multiple linear regression analysis which was conducted to find out to what level and to what direction self-compassion dimensions influenced social physique dimensions, self-compassion dimension was found to have a high association with the physical appearance comfort dimension of self-compassion, $R=0.60, R^{2}=0.36, p<.01$. Selfcompassion areas explain about $36 \%$ of the total variance of physical appearance comfort dimension $\left[F_{(6,455)}=43.45, p<.000\right]$. When the analysis results of the significance of regression coefficients were analyzed, it was found that the dimension of self-kindness $(t=-2.592, p<.010)$, selfjudgment $(t=2.541, \mathrm{p}<.011)$, isolation $(t=2.118, p<.035)$, mindfulness $(t=-9.641, p<.000)$ and overidentification $(t=2.302, p<.022)$ were significant predictors of physical appearance comfort dimension while only the dimension of common humanity was not a significant predictor of physical appearance comfort dimension $(t=-1,136, p>$.256). Similarly, self-compassion dimensions were found to have a significant association with the expectation of being evaluated negatively, $R=0.38, R^{2}=0.15, p<.01$. Self-compassion areas explain about $15 \%$ of the total variance of physical 
appearance comfort dimension $\left[F_{(6,45)}=12.88, p<.000\right]$. When the analysis results of the significance of regression coefficients were analyzed, it was found that the dimensions of selfkindness $(t=-3.222, p<. .001)$, self-judgment $(t=2.714, p<.007)$, common humanity $(t=3.285, p<.001)$ and isolation $(t=2.119, p<.035)$ were significant predictors of the expectation of being evaluated negatively, while the dimensions of mindfulness ( $t=-1.051, p>.058)$ and over-identification $(t=1.900, p>$.294) were not found to be significant predictors of the expectation of being evaluated negatively.

\section{Discussion and Recommendations}

This study examined whether self-compassion of athletes was a significant predictor of social physique anxiety. First, it was researched whether the athletes' social physique anxiety differed in terms of gender and it was found according to the results of independent samples t-test that the average scores of physical appearance comfort and the expectation of being evaluated negatively did not differ significantly in terms of gender. When the literature is reviewed, it can be seen that there are studies which have shown that social physique anxiety scores did not differ significantly in terms of gender (Koparan, Öztürk \& Korkmaz, 2010; Yılmaz, Bektaş \& Beyazoğlu, 2013); while there are also studies which show that the scores differed significantly and that women showed higher social physique anxiety (Haase, Prapevessis \& Owens, 2002; Berry \& Howe, 2004; Çepikkurt \& Çoşkun, 2010). The fact that men today care about their appearances at least as much as women is definitely a valid result for male athletes whose bodies are on the forefront. The view that physical appearance can decrease a person's performance can also be effective in this result.

Pearson product-Moment correlation coefficient was used to examine the association between the students' social physique anxiety and their self-compassion. According to the results, a negative association was found between the physical appearance comfort sub-dimension of social physique anxiety and self kindness, common humanity and mindfulness sub-dimensions of self-compassion; while a positive significant association was found between self-judgment, isolation and over identification. While a negative association was found between the expectation of being evaluated negatively sub-dimension of social physique anxiety and self kindness and mindfulness subdimensions of self-compassion; a positive significant association was found between self-judgment, isolation and over identification. Especially researches conducted with female athletes support the findings of this study. Researches show that as self-compassion scores increase, social physique anxiety scores decrease (Mosewich, Kowalski, Sabiston, Sedgwick \& Tracy ,2011; Mosewich, Crocker, Kowalski, \& DeLongis, 2013). Being nice to self instead of self-criticism when confronted with difficult situations, accepting the hardships as a part of life and maintaining this situation in a balanced way will help athletes to overcome the negative self-assessments they experience for their bodies. Since athletes think that they are assessed not only in terms of performance, but also in terms of appearance, it can be claimed that self-compassion, which is associated with positive mental states, will make a person to respect his/her body and make it easier to fight with problems surrounding his/her body.

The study also researched whether the athletes' self-compassion was a significant predictor of their social physique anxiety. Multiple linear regression was used to this end. According to the results, it was found that self-kindness, self-judgment, isolation, mindfulness and over-identification were significant predictors of physical appearance comfort while common humanity was not found to be a significant predictor of physical appearance comfort. When the effect sizes of multiple linear regression analysis results are taken into consideration, it is clear that self-compassion elements differ in terms of their predictive powers on physical appearance comfort. When the effect sizes are considered, it can be seen that mindfulness has the greatest effect with .41 , followed by selfkindness with .12, self-judgment .11, over-identification .11 and isolation .10. Negative beta values 
of the elements of self-kindness, common humanity and mindfulness shows that there is a counter association between these. That is, as the aforementioned self-compassion scores increase, the athletes' physical appearance comfort scores decrease.

Similarly, when the expectation of being evaluated negatively sub-dimension analysis results were examined, it was found that the elements of self-kindness, self-judgment, common humanity and isolation were significant predictors of the expectation of being evaluated negatively, while mindfulness and over-identification were not found to be significant predictors of the expectation of being evaluated negatively. When the effect sizes of multiple regression analysis results are considered, it is clear that self-compassion elements differ in terms of their predictive powers on the expectation of being evaluated negatively. When the effect sizes are considered, it can be seen that common humanity has the greatest effect with .31 , followed by self-kindness with .25 , selfjudgment .21 and isolation .17. Negative beta values of the element of self-kindness shows that there is a counter association between these. That is, as the aforementioned self-kindness scores increase, the athletes' the expectation of being evaluated negatively scores decrease. These results support the view that developing these elements of self-compassion will help the athletes to decrease social physique anxiety.

These results are in parallel with the results of studies in literature. In their study they conducted with 252 female athletes, Magnus, Kowalski and McHugh (2010) reported that self-compassion is a significant predictor of social physique anxiety. Similarly, in their study they conducted with 151 female athletes, Mosewich et al. (2011) found that elf-compassion had a quite significant descriptive power on social physique anxiety. In addition, researchers stated that self-compassion was a tool that contributed to manage conscious emotions by decreasing the negative effects of women athletes in sports competitions. Similarly, Ferguson, Kowalski, Mack and Sabiston (2014) stated that elements of self-compassion such as self-kindness, which helped athletes to assess themselves positively, were quite effective against experiences which caused athletes to assess themselves negatively and to endanger themselves due to difficult experiences. In this context, it can be said that self-compassion is an important source for athletes to decrease the effects of thoughts and behaviors which worry them such as social physique anxiety. Psychoeducational programs can be organized to increase self-compassion which will help to remove the effects of negative selfassessment of athletes. Thus, athletes will be able to take the possible negative effects of negative self-assessment under control. This will enable the manipulation of a significant stressor by helping athletes to accept themselves with their every aspect and thus they will be more motivated to succeed. Self-compassion can also function as an effective coping source for the difficult processes of athletes.

Although self-compassion was analyzed as an independent variable in this study, it is possible to talk about implied variables which influence self-compassion. Thus, in future studies, different variables which are thought to play mediator role between self-compassion and social physique anxiety can be addressed. In addition, this study was conducted on both male and female athletes. Future studies can be conducted only on females. As a conclusion, it can be seen that selfcompassion plays an important role in predicting social physique anxiety.

\section{References}

Adams, C. E. \& Leary, M. R. (2007). Promoting Self-Compassionate Attitudes Toward Eating Among Restrictive and Guilty Eaters. Journal of Social and Clinical Psychology, 26, 1120- 1144. doi: 10.1521/jscp.2007.26.10.1120

Mülazımoğlu-Ballı Ö. \& Aşçı F. H. (2006). Sosyal fiziksel kaygı envanterinin geçerlik ve güvenirlik çalışması. Spor Bilimleri Dergisi, 17, 1, 11-19. 
Epli Koç, H., \& Ermiş, E. (2016). Self-compassion as a predictor of social physique anxiety in athletes. Journal of Human Sciences, 13(3), 5214-5222. doi:10.14687/ihs.v13i3.4120

Aş̧̧, F. H., Tüzün, M., \& Koca, C. (2006). An Examination Of Eating Attitudes And Physical Activity Levels Of Turkish University Students With Regard To Self-Presentational Concern. Eating Behaviours, 7, 362-367. doi:10.1016/i.eatbeh.2005.11.011

Akın, Ü., Akın, A. \& Abacı, R. (2007). Öz-Duyarlık Ölçeği: Geçerlik ve Güvenirlik Çalışması. Hacettepe Üniversitesi Ë̆itim Fakültesi Dergisi, 33, 1-10.

Berry T. R. \& Howe BL. (2004). Effects of Health-Based and Appearance Based Exercise Advertising on Exercise Attitudes, Social Physique Anxiety and Selfpresentations in an Exercise Setting. Social Behavior and Personality, 32, 1-12. doi: 10.2224/sbp.2004.32.1.1

Campos, D., Cebolla, A., Quero, S., Bretón-López, J., Botella, C., Soler, J. \& Baños, R. M. (2015). Meditation and happiness: Mindfulness and selfcompassion may mediate the meditation-happiness relationship. Personality and Individual Differences, 93, 80-85. doi: 10.1016/j.paid.2015.08.040

Crawford S. \& Eklund R. C. (1994). Social Physique Anxiety, Reasons for Exercise, and Attitudes Toward Exercise Settings. Journal of Sport and Exercise Psychology, 16, 70-82.

Çepikkurt, F. \& Çoşkun, F. (2010). Social Physique Anxiety and Body Image Satısfactıon Levels of Collegian Dancers. Pamukeale Journal of Sport Sciences, 1, 2, 17-24.

Eklund, R.C., \& Crawford, S. (1994). Active Women, Social Physique Anxiety, and Exercise. Journal of Sport \& Exercise Psychology, 16, 431-448.

Ferguson, L. J., Kowalski, K. C. , Mack, D. E. \&. Sabiston, C. M.(2014). Exploring Self-Compassion and Eudaimonic Well-Being in Young Women Athletes. Journal of Sport \& Exercise Psychology, 36, 203216. doi: 10.1123 /jsep.2013-0096.

Hagger, M.S. \& Stevenson, A. (2010). Social Physique Anxiety and Physical Self-Esteem: Gender and Age Effects. Psychology \& Health, 25(1), 89-110. doi:10.1080/08870440903160990.

Haase, A. M., Prapevessis H. \& Owens, R.G.(2002). Perfectionism, Social Physique Anxiety and Disordered Eating: A Comprasion of Male and Female Elite Athletes. Psychology of Sport and Exercise, 3, 209-222. doi: 10.1016/S1469-0292(01)00018-8

Hart, E. A., Leary, M. R., \& Rejeski, W. J. (1989). The Measurement of Social Physique Anxiety. Journal of Sport and Exercise Psychology, 11, 94-104.

Heffernan, M., Quinn Griffin, M. T., McNulty, R., \& Fitzpatrick, J. J. (2010). Self-compassion and emotional intelligence in nurses. International Journal of Nursing Practice, 16, 366-373. doi:10.1111/j.1440172X.2010.01853.x

Hollis-Walker, L., \& Colosimo, K. (2011). Mindfulness, self-compassion, and happiness in non-meditators: A theoretical and empirical examination. Personality and Individual Differences, 50(2), 222-227. doi:10.1016/j.paid.2010.09.033

Hurst, R., Hale, B., Smith, D. \& Collins D. (2000). Exercise Dependence, Social Physique Anxiety, and Social Support İn Experienced and İnexperienced Bodybuilders and Weightlifters. British Journal of Sports Medicine, 34,6, 431-435. doi:10.1136/bjsm.34.6.431

Greenleaf, C. (2002). Athletic Body İmage: Exploratory İnterviews With Former Competitive Female Athletes. Women in Sport and Physical Activity Journal, 11, 63-88.

Koparan, Ş., Öztürk, F. \& Korkmaz, N.H. (2010). Beden Eğitimi Öğretmenlerinin Öz-Yeterlik Alg1sı ve Sosyal Fizik Kaygı Düzeylerinin Bazı Değisskenler Açısından Incelenmesi. E-Journal of New World Sciences Academy, 5, 4, 286-293.

Krane, V., Stiles-Shipley, J. A., Waldron, J. \& Michalenok, J. (2001). Relationships Among Body Satisfaction, Social Physique Anxiety, and Eating Behaviors in Female Athletes and Exercisers. Journal of Sport Behavior, 24, 247-264.

Martin, K.A. \& Mack, D. (1996). Relationship Between Physical Self-Presentation and Sport Competition Trait Anxiety: A Preliminary Study. Journal of Sport Exercise Psychology, 18, 75-82.

Mosewich, A. D., Vangool, A. B., Kowalski, K. C., \& McHugh, T. F. (2009). Exploring Women Track and Field Athletes' Meanings of Muscularity. Journal of Applied Sport Psychology, 21, 99-115. doi: 10.1080/10413200802575742

Mosewich, A. D., Kowalski, K, C. Sabiston, C. M., Sedgwick, W. A. \& Tracy, J. L. (2011). Self-Compassion: A Potential Resource for Young Women Athletes. Journal of Sport \& Exercise Psychology, 33, 103-123

Mosewich, A. D., Crocker, R. R. E, Kowalski, K. C. \& DeLongis, A. (2013). Applying Self Compassion in Sport: An Intervention With Women Athletes. Journal of Sport \& Exercise Psychology, 35, 514-524.

Mosewich A.D. (2013). Self-compassion as a resource to manage stress in women athletes. (Unpublished doctoral dissertation). University of British Columbia, Vancouver, BC, Canada. 

Sciences, 13(3), 5214-5222. doi:10.14687/ihs.v13i3.4120

Magnus, C. M. R., Kowalski, K. C., \& McHugh, T.-L. F. (2010). The Role of Self- Compassion in Women's Self-Determined Motives To Exercise And Exercise-Related Outcomes. Self and Identity, 9, 4, 363 382. doi: 10.1080/15298860903135073

Mülazımoğlu-Ballı, Ö. \& Aşçı, F. H. (2006). "Sosyal Fizik Kaygı Envanteri””nin Geçerlik ve Güvenirlik Çalışması. Spor Bilimleri Dergisi, 17 (1), 11-19.

Neff, K. D. (2003a). Self-Compassion: An Alternative Conceptualization of a Healthy Attitude Toward Oneself. Self and Identity, 2, 2, 85-102. doi: $10.1080 / 15298860390129863$

Neff, K. D. (2003b). The Development and Validation of a Scale to Measure Self-Compassion. Self and Identity. 2,3, 223-250. doi: 10.1080/15298860309027

Neff, K. D., Hsieh, Y., \& Dejitterat, K. (2005). Self-Compassion, Achievement Goals, and Coping With Academic Failure. Self and Identity, 4, 263-287. doi:10.1080/13576500444000317

Neff, K. D.,\& Vonk R. (2009). Self-Compassion Versus Global Self-Esteem: Two Different Ways of Relating To Oneself. Journal of Personality, 77, 23-50. doi: 10.1111/j.1467-6494.2008.00537.

Neff, K. D. (2009). Self-compassion. In M.R. Leary \& R.H. Hoyle (Eds.), Handbook of Individual Differences in Social Behavior (pp. 561-573). New York: Guilford Press.

Özdemir, Ü. A. (2014). Bedenin Metalaşma Sureci ve Reklam Yoluyla İmaj Yaratımı. G. Ilıcak Aydınalp (Ed). İmaj Üretimi. Ankara: Nobel Yayın Dağıtım

Pyszczynski, T., Greenberg, J., Solomon, S., Arndt, J., \& Schimel, J. (2004). Why do people need selfesteem? A theoretical and empirical review. Psychological Bulletin, 130, 435-468. DOI:10.1037/0033$\underline{2909.130 .3 .435}$

Sicilia A, Sáenz-Alvarez P., González-Cutre D. \& Ferriz R. (2014). Exercise Motivation And Social Physique Anxiety in Adolescents. Psychologica Belgica, 54,1, 111-129. doi: 10.5334/pb.ai

Yılmaz, I., Bektaş, F., Beyazoglu, G. (2013).Evaluating The Relationship Between Physical Education Teachers Social Physique Anxiety Levels And Job Satisfaction. Turkish Journal of Sport and Exercise, $15,2,45-50$. 